to accept discoveries and classifications made abroad more readily than those made at home. The terms at present employed in British archæological works relating to the phases of the Iceage certainly might be cited in support of this contention. In I894, when preparing the third edition of the "Great Ice Age" -of which the work under review may be regarded in some respects as a fourth edition-Prof. Geikie recognised four phases of glaciation, which he named: (I) Scanian, (2) Saxonian, (3) Polonian, (4) Mecklenburgian. British students of ancient man have never adopted these terms; they prefer those which Prof. Penck introduced nine years laterin 1903-(I) Günzien, (2) Mindelien, (3) Rissien, (4) Würmien. Geikie's terms were founded on a study of the glacial deposits of Europe generally; Penck's were the result of a study of glacial deposits in Alpine regions. If priority is to count the British terms have much to commend them. In the present work Prof. Geikie correlates the two systems of nomenclature-the "Scanian" corresponding to the "Günzien," the "Saxonian" to the "Mindelien," the "Polonian" to the "Rissien," and the "Mecklenburgian" to the "Würmien."

In charting the glacial phases of the Pleistocene period, Prof. Geikie and Prof. Penck have provided students of ancient man with an invaluable series of milestones to guide them into that period which is supposed to cover the evolution of modern man. The Heidelberg mandible is regarded by Prof. Geikie as the oldest human remains yet found on the Continent of Europe, and is assigned by him to the interval between the first and second periods of glaciation. He is not fully convinced that eoliths and sub-crag implements are really of human workmanship.

One of the most important contributions made by Prof. Geikie to our knowledge of ancient man refers to the Neolithic period. In the formations and deposits of that time Scotland is particularly rich. From a study of these he has divided the Neolithic period into four phases: (I) lower "forrestian," (2) lower "turbarian," (3) upper "forrestian," (4) upper "turbarian." Each of these phases is marked by a change of climate, a change of flora, and an alteration in the relationship of land and sea. The human remains and objects of culture found in the caves at Oban, usually ascribed to the transitional stage, between the Palæolithic and Neolithic periods, are regarded by Prof. Geikie as belonging to the late Neolithic phase, named up him upper "turbarian."

Prof. Geikie has never indulged in, or countenanced, wild speculation. It is therefore of interest to note the estimate he has formed of the duration of the Pleistocene period. After forty years of study, largely devoted to an examination of glacial deposits, he is of opinion that an allowance of at least 600,000 years must be made for the duration of the Pleistocene period. Man's presence in Europe may, in his opinion, be regarded as extending over a period of 250,000 or perhaps 500,000 years.

A. $\mathrm{K}$.

\section{THE CULTIVATION OF MEDICINAL PLANTS IN ENGLAND.}

THE question has been asked whether the con1 ditions created by the war in Europe has made it desirable to give attention to the cultivation of medicinal plants in England. The answer is a decided affirmative, but some qualification is needed. Cultivated drugs can never compete with those from wild plants if price prevails over all other considerations. It was only fine appearance and high reputation for therapeutic activity which enabled English aconite, belladonna, digitalis, and henbane to command four times the price of the imported drugs. As it was, severe competition had of late years restricted the use of home produce more and more until it attained relatively small limits.

Much care and skill are needed in preparing the finest qualities of drugs for market, and only comparatively high prices repay this initial trouble and expense. Again, there is only a limited outlet for drugs in general, so that the market is easily overloaded, and when this occurs the highest grades often suffer most as regards depreciation in value. For example, the supply of English-grown belladonna leaves began to exceed the demand in about the year I9oo, and a few years ago they were selling in competition with wild Continental drugs--at less than cost. Acreage under belladonna naturally shrank, and, in fact, its cultivation became restricted to a few "materia medica," or drug farms, connected with factories for making extract. Similar experiences led to the cultivation in England of all but a few medicinal plants (e.g. valerian, poppy, and dill) being controlled by four firms growing only sufficient for their own requirements. Two successive wet winters, causing excessive loss of plants, had made this season's crops insufficient for normal demands, and the onset of hostilities quickly raised prices to famine rates. High prices restrict usage and stimulate new sources of production until prices become normal again. Both these factors are at work now war in Europe threatens to last for a considerable period, and the first in the field of drug cultivation are likely to reap a profitable harvest.

The writer gave details of cultivation of various drugs in the Journal of the Board of Agriculture for September. Within a week an advertisement in the druggist's trade paper "wanted fertile seeds of belladonna, digitalis, henbane, stramon ium; also live roots chamomile, coltsfoot, valerian, spearmint." This illustrates a great initial difficulty, that of obtaining a supply of dormant plants or seeds.

British medicinal plants fall into four categories :-

(I) Drugs which have long been cultivated in this country, but were gradually being ousted by foreign wild products, viz. belladonna, henbane, aconite, digitalis, and valerian. All these, except aconite, are now in great demand. Chamomile (of recent years practically grown only for distillation of oil from flowers) are now almost unob- 
tainable owing to Belgian supplies being cut off. Of other aromatic plants grown for distilling purposes, peppermint is not likely to be affected, but spearmint and probably lavender will be dearer. Efforts to extend drug growing will centre around belladonna, henbane, valerian, and chamomile. The first year's returns as regard size of crops will be small, but they will increase rapidly afterwards if remunerative prices are maintained.

(2) Medicinal plants which held their own in competition with foreign supplies:-Dandelion, dill, white poppy, and red poppy petals. Of these the first and last grow wild. The second is as conditions :- Barberry bark, bittersweet, broom, buckthorn berries and bark, colchicum, coltsfoot, conium, elder flowers and leaves, male fern, rose petals, sweet flag, and yarrow. Considerable sums could be made by organised collection of these (and also of wild dandelion root and digitalis leaves). The most promising from a moneymaking point of view is male fern rhizome, of which large quantities are needed at once. There is plenty in many localities to be had for the gathering.

(4) Medicinal plants rarely cultivated in this country, but worthy of more attention:-Golden

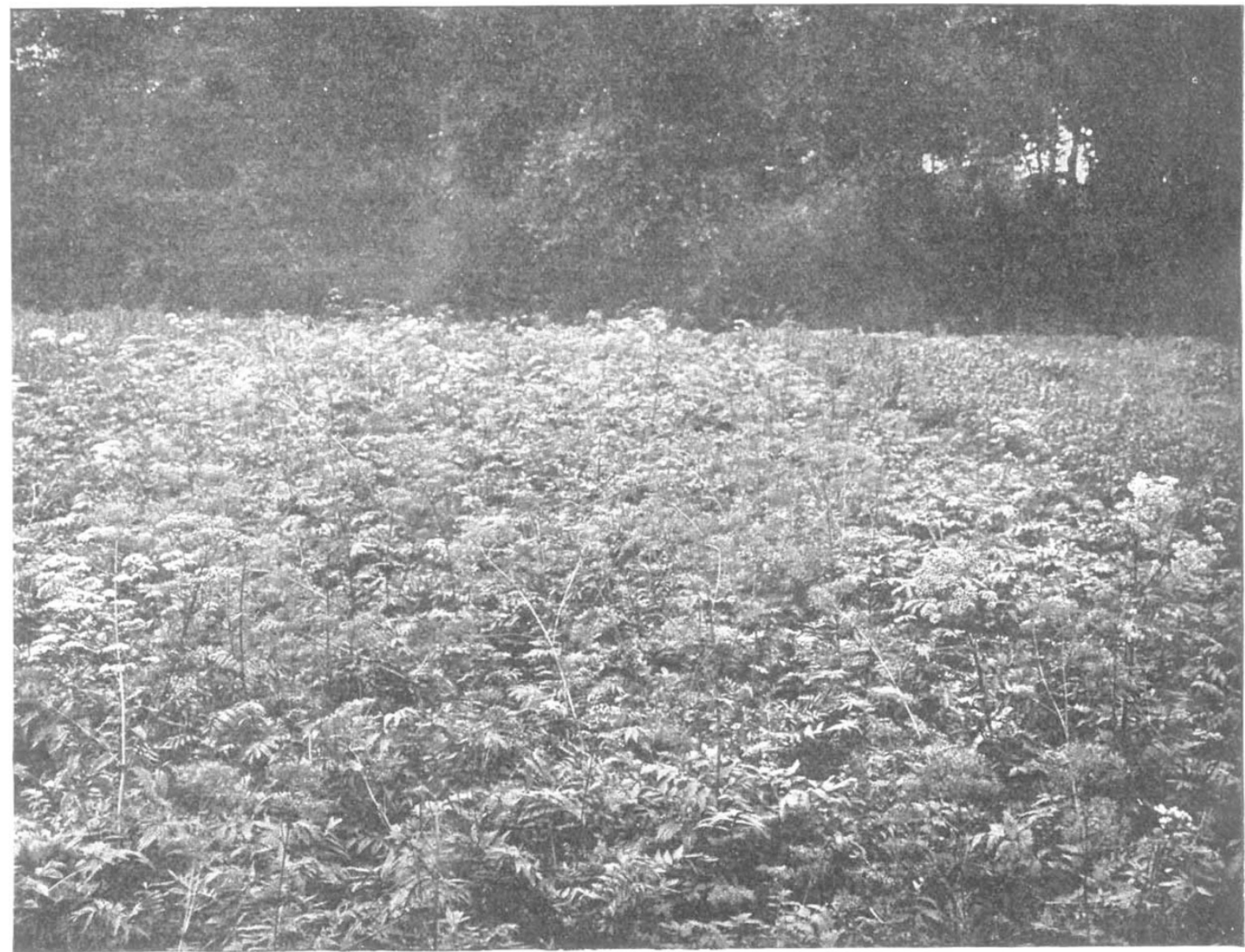

Frg. I.-A plantation of English Valerian (Valeriana officinalis, L.). From the Journal of the Board of Agriculture, By permission of H.M. Stationery Office.

easily grown by farmers as cereal crops. Poppyhead production is a special industry in Lincolnshire. Many of the "botanical herbs" sold by medical herbalists are grown at Carshalton, Surrey, but not in sufficient quantities to supply all home requirements. There is undoubtedly much greater scope at present for the cultivation of medicinal plants in this category. Culinary herbs (marjoram, sage, thyme, etc.) are also worthy of attention.

(3) Plants which grow wild, but are not collected in quantity in this country under normal NO. 2346, VOL. 94$]$ seal, fennel, and thornapple. The last two are easily grown, and in much demand now. The first-named promises rich reward to the successful experimenter.

Most medicinal plants belong to the category of weeds, so that they are not difficult to raise if the ground is kept free from other growths. It is the need for having some facilities for drying leaves and roots that may prevent medicinal herbs being grown by cultivators of other crops as a paying side-line. Medicinal leaves are valued solely by appearance, this being brighter the more 
quickly they are dried. In the case of potent drugs, such as belladonna and digitalis, it is imperative that the leaves do not become "heated," this being prevented by spreading in very thin layers. Large growers of drug products have proper drying plant, but a heated glasshouse could be readily converted into a drying shed.

The labour problem is another great hindrance to cheap supplies of British-grown medicinal plants. On the Continent wild plants are collected at odd times usually when harvesting is over. On English drying farms the crops are taken when plants are at their best, the time of collection having in some cases an important influence on the therapeutic effect of the drug. This point is fully recognised in the theory of medi- by the European war. When this is over and foreign supplies are again available it is to be hoped that druggists, wholesale and retail, will give that moral and patriotic support needed to prevent it again relapsing.

\section{W. A. Whatmough.}

\section{THE BRITISH ASSOCIATION IN NEW} SOUTH WALES.

Sydney, August 27.

THESE lines are written a few hours after the departure of our visitors for Brisbane, where two addresses will mark the conclusion of the first Australian Meeting of the British Association. When the shadow of this cloud of war has passed away, the Australian Meeting w i 11 stand out as a notable one. Its total of 4700 $\mathrm{members}$ is $\mathrm{a} b$ o u $\mathrm{t}$ IOOO greater $t h$ a $n$ $\mathrm{t} h \mathrm{a} t$ of any other meeting. Much solid work has been done in the various $\mathrm{sec}-$ tions, $w$ h i 1 e great public interest has been aroused by the lectures and addresses. Those $\mathrm{w} \mathrm{h} o$ believed that the outbreak of war would have a serious effect upon it have learned $t \mathrm{~h}$ a $\mathrm{t}$ their fears were groundless. Though $\mathrm{t} \mathrm{h}$ e minds of all have been filled with anxious

FIG. 2.-Cutting English belladonna. (Atropa belladonna) From the Journal of the Board of Agriculture. By permission of H.M. Stationery Office.

cine, but in practice it is usually lost in the modern craze for "cheapness." The cheeseparing policy at times defeats its own object, as the proportion of actual drug in a dose of medicine is so small that doubling the cost of crude drugs would make little or no difference in ultimate cost. A ten-minim dose of digitalis tincture from Britishgrown drug costs $I / 50 o t h$ penny more than that from imported drug, quite a negligible quantity in comparison with the greater certainty of action.

The drug trade is likely to regret bitterly for some time to come the policy which led to the virtual exclusion of home-grown drugs. A considerable extension of the acreage under medicinal plants will result from the conditions created NO. 2346 , VOL. 94$]$ thoughts of what may be happening to our soldiers and sailors far away in this crisis of the Empire's fortunes, on all hands there is ample evidence that the meeting has been an unqualified success.

On Thursday, August 20, our visitors arrived from Melbourne, about io a.m., in three special trains, and the arrangements for their speedy transit to the houses of their hosts worked admirably. Early in the afternoon the Reception Room at the University began to be thronged with members inquiring for their various tickets, and anxious to secure places in the excursions without delay, which had been arranged for the week-end.

The President delivered the second half of his 